\title{
RESILIENCE OF SOCIAL HOUSING SYSTEMS IN VIENNA, AMSTERDAM, AND COPENHAGEN
}

\author{
Sasha Tsenkova
}

\section{Introduction, Objectives and Methodology}

The crisis that started in the mortgage markets of the United States in 2007-2008 has had dramatic and sustained impacts on people and housing systems throughout the world. These complex and interlinked crises exposed vulnerabilities of housing markets and low-income households, pointing to the need to build resilience through better policy tools and sustainable provision of social housing. In the context of fiscal austerity and budget cuts in all European countries, the future, purpose and form of social housing are being questioned and re-examined. This is of great importance to society and to our cities, where over $80 \%$ of the people live and work, particularly given the rapid growth of urban poverty and vulnerability. Comparative studies indicate a renewed emphasis on the supply of social housing in some European countries and city-wide initiatives to encourage private and non-profit provision to minimise 'poverty trap' effects (CECODHAS, 2012; Scanlon et al., 2015). In the post-crisis era, countries with unitary models and a strong social housing legacy have introduced a range of policy instruments and economic stimulus packages to promote supply-side responses in large metropolitan areas.

Housing providers and funding regimes have adjusted to the new environment, and some innovative entrepreneurial models have emerged in European cities (Pogglio and Whitehead, 2017). The emphasis is very much on diversifying social housing suppliers, public/private partnerships and the development of mixed communities in the context of urban regeneration. While there is a growing commitment to social housing in the political rhetoric, few countries, mostly with unitary systems, have identified new policy instruments to ensure that the investment necessary to meet the need for affordable housing will actually occur (Bardhan et al., 2012; CECODHAS, 2012).

This chapter aims at exploring the resilience of social housing systems in times of crisis. It focuses on the policy and practice of three conceptually appropriate case studies- the Netherlands, Austria and Denmark. These are examples of unitary housing systems with sustained investment in new social housing provision, a range of private and non-profit housing providers and a wide range of fiscal and regulatory instruments enhancing the competitive performance of the social housing sector (Kemeny et al., 2005; Matznetter, 2002). The emphasis is on housing policy and social housing system performance in the capital cities, where the impact of the fiscal crisis is more visible. The hypothesis is that unitary social housing systems, despite their 
unique characteristics and institutional legacy, are more resilient in institutional, economic and social terms. This may be attributed to the robustness and the resourcefulness of social housing institutions and/or to better policy intervention in the post-crisis period. The research has three interrelated objectives:

- To develop a framework for comparative analysis of system resilience of social housing;

- To identify fiscal, financial and regulatory instruments implemented to ensure growth in the system and its resilience

- To identify patterns of resilience in institutional, economic, social and environmental terms.

The research methodology, which employs both qualitative and quantitative techniques, was structured in two parts. First, country-specific reform strategies were explored more broadly through review of the literature-country monographs on social housing, officially published documents, reports, working paper series and journal articles. Second, the collection of quantitative indicators (time-series data) was carried out though a survey instrument. Data on social housing at the city level (Vienna, Amsterdam and Copenhagen) were organised in four thematic blocks: (i) new housing construction and investment, (ii) financial indicators, (iii) affordability indicators and (iv) quality indicators.

Additional data on supply-side responses by social housing providers were collected through primary research to illustrate the diversity of experiences. The emphasis was on output, quality and diversity of social housing as well as business strategies to access land and long-term finance. Key informant interviews in Vienna, Amsterdam and Copenhagen were carried out in 2009 with close to 40 housing policy-makers, social housing providers and municipal planners with pertinent expertise and immediate involvement in social housing policy implementation. A follow-up process of data validation took place in March 2013.

\section{Theoretical Context: Models of Social Housing Provision and Policy Instruments}

The research is informed by the convergence-divergence paradigm for comparative housing studies (Kemeny and Lowe, 1998) and advances the notion that European systems of social housing provision have become less similar over time, with diverging experiences likely to accelerate in the future. The core idea of the convergence theory is that similarity of economic and demographic development in different countries will lead to converging housing policies, despite differences in ideology, politics and institutional structures (see Tsenkova 2009 for discussion on these issues). Esping-Andersen (1990) made perhaps the most significant attempt to identify patterns of dissimilarity based on distinct welfare state regimes. The approach has been refined through the comparative housing studies of Kemeny (1995), with the development of typologies of 'housing policy regimes'. In the spirit of divergence debates, scholars argued that despite similarities, European countries have distinctive housing systems and there is no evidence of convergence (Doling, 1997; Donner, 2000).

The research focuses on comparative analysis of countries with unitary systems of social rented housing where the sector operates like a 'social market' in direct competition with other tenures. The institutional arrangements favour non-state ownership by non-profit landlords, rents are set below-market level but tend to be sensitive to demand and allocation extends access to a more diverse income group. Distortions in pricing are less prevalent, since rental systems not only ensure cost recovery for services, but also allow rent-setting to be adjusted to a range 
of property attributes (Kemeny, 1997; Kemeny et al., 2005). In Western Europe, the Netherlands, Sweden, Denmark and Austria exemplify the characteristics of unitary systems. These relationships sketched in broad strokes reflect very general aspects of the role of social housing in unitary systems. The supply of new social housing, in particular, is dependent on the availability of fiscal, financial and regulatory instruments to encourage provision and to deal with the frontend loaded nature of housing costs (Carmona et al., 2003; Tsenkova, 2009).

Different countries have experimented with a range of fiscal instruments requiring direct expenditures of the government (grants, subsidies, tax incentives), or indirect, such as depreciation allowances or rent control. England and Austria rely on capital grants, Denmark on interest rate subsidies and the Netherlands has abolished direct subsidies, having first provided the housing associations with payments designed to relieve them of debt (Boelhouwer et al., 2006). Some countries (e.g. Austria, England and France) subsidise a range of housing suppliers directly (with conditions on production levels and rents), reducing house builders' and landlords' costs in social housing (Angel, 200; Donner, 2000). A second major stream of subsidies, as the main instrument of housing policy, is applied in all countries through housing vouchers, rent supplements or housing benefits. These fiscal instruments in unitary systems operate with various levels of efficiency, transparency and distributional equity (Oxley, 1995; Scanlon et al., 2015).

Financial instruments to encourage new supply of social housing relate to the availability of long-term finance and the diversity of mortgage products. In most countries with unitary models, private finance has become a dominant source of low-cost finance and is obtained mainly from banking intermediaries. Borrowing costs from private sector institutions are subsidised in Denmark and England, while borrowing is guaranteed in the Netherlands (Scanlon and Whitehead, 2007). Finally, tenants provide up to $2 \%$ of the funds for new social housing in Denmark and up to $10 \%$ in Austria, with additional grants available from local municipalities (Tsenkova, 2014).

A wide range of regulatory policies define housing standards in the social housing sector and the way social landlords and providers operate through supervision, auditing and control over allocation procedures. Regulatory instruments and operational practices allow the physical production, allocation and consumption of housing without imposing restrictions on main institutions and agents in the market (see Tsenkova, 2021). The regulatory environment has evolved to enhance efficiency in production and allocation decisions by making social providers more responsive to household preferences (e.g. the Delft model of allocation). Second, policies in this category include reduction in land costs to promote housing investment in social housing. Inclusionary zoning, planning agreements, provision of free public land and development land taxes have been used to extract some of the 'excess profit' of the landowner and/or provide incentives to developers, particularly in the context of regeneration projects (Buitelaar and De Kam, 2011). The Dutch planning system provides the most comprehensive 'solution' in Europe, while in England and France planning negotiations may lead to a provision of $20-50 \%$ of social housing in large-scale projects.

\section{Conceptual Framework}

The conceptual framework brings more established concepts of housing policy analysis with concepts related to resilience thinking (Tsenkova, 2021). More specifically, it is designed to explore the resilience of unitary social housing provision systems focusing on new supply-the most dynamic element of the system. It applies the concept of resilience, which has a wellestablished history in environmental research, engineering, psychology, sociology and economics, but has not been explored in housing studies. In this way of thinking, resilient systems have the ability to thrive, improve or reorganise themselves in a healthy way in response to stress 


\section{Social Housing Provision}

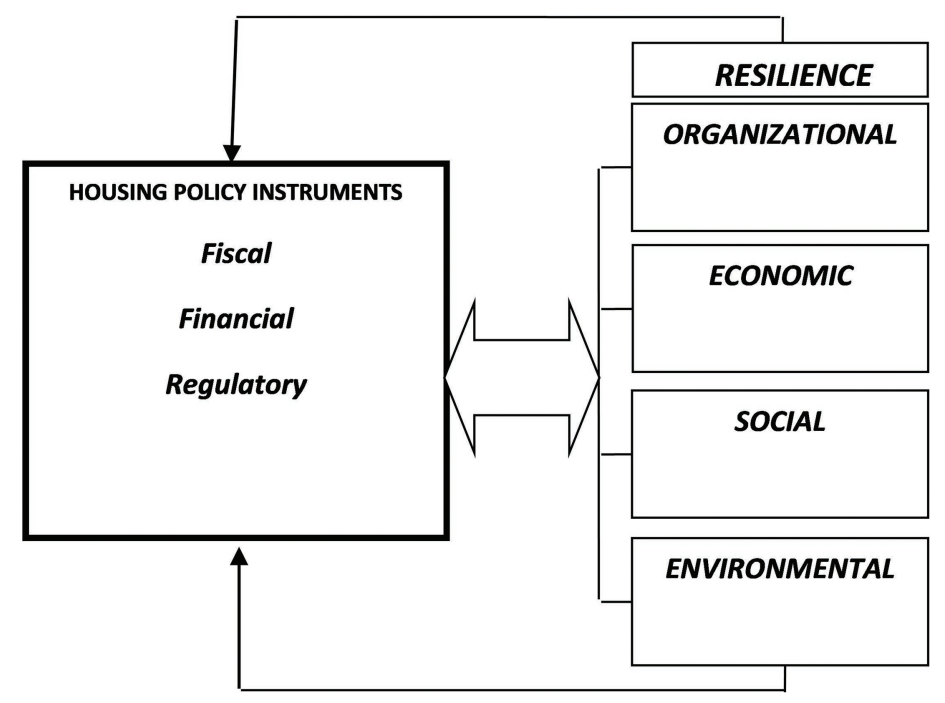

FIGURE 13.1 Conceptual Framework: Resilient Social Housing Systems.

Source: Sasha Tsenkova.

(Vale et al., 2014). Such systems demonstrate greater adaptive capacity and can maintain system function in the event of disturbances. Understanding complex adaptive systems, such as social housing in large urban centres, and their resilience, can be defined as the ability to withstand, recover from and reorganise in response to crises. Function is maintained, but system structure may not be. Key properties that contribute to resilience are diversity and redundancy, the presence of multiple smaller systems that are relatively independent and responsive regulatory feedbacks (Walker et al., 2006).

Defining Resilience. Most discussions of resilience agree that it is a multifaceted concept and should be understood and measured across multiple dimensions, including physical, social, economic, institutional and ecological fronts. The conceptual framework (Figure 13.1) explores the impact of housing policy packages combining fiscal, financial and regulatory policy instruments on the social housing system and its performance during the times of financial crisis since 2008. The comparative analysis focuses on four dimensions of systems resilience-institutional, economic, social and environmental - to quantify various types of social housing system responses (see Walker and Salt, 2012). Resilience is the ability of a system to withstand stresses and to adapt to sudden shocks. For the purposes of this research, resilience of the social housing system is defined as the ability of social providers to contain the effects of financial and fiscal stress during times of crisis, and to carry out maintenance and redevelopment activities in their social housing portfolio in a manner that minimises disruption to affordability and mitigates the impact on housing quality. Enhancing the resilience of social housing systems minimises economic and social losses during a crisis and allows moderate growth in the system. It can be achieved by the ability of a social provider to perform more efficiently and effectively to absorb a shock, if it occurs, and to recover quickly after a shock.

More specifically, a resilient system is one that shows the following attributes:

- Robustness: strength, or the ability of the system to withstand a given level of stress without suffering degradation or loss of function; 
- Resourcefulness: the capacity to identify problems and mobilise resources (financial, technical, physical) to counteract disruption in the system;

- Redundancy: the extent to which systems/subsystems are substitutable, that is, capable of satisfying functional requirements in the event of disruption, degradation or loss of functionality.

(Walker et al., 2006)

Notwithstanding the importance of this institutional dimension, resilience encompasses three interrelated dimensions-economic, social and environmental (McCarthy et al., 2011). The economic dimension of resilience refers to the capacity to reduce both direct and indirect economic losses resulting from reduced financial and fiscal support and continue to grow. Housing providers adopt different business strategies for land acquisition and capital mobilisation and that influence important outcomes in terms of output, costs and quality. The social dimension of resilience consists of measures specifically designed to address communities' need for affordable housing through better access, social integration, affordability and choice. Important measure of affordability is the share of households receiving demand-based support in new social housing: a higher share implies greater vulnerability and potential for social exclusion. The environmental dimension of resilience refers to the ability of the social housing portfolio to provide access to affordable, good-quality housing through sensitive integration in neighbourhoods, access to transit, community facilities, jobs and schools. It also refers to standards and innovation to improve environmental performance and the energy efficiency of new social housing. Further, housing provision is examined as a dynamic process of interaction between public and private institutions with a focus on the performance of major social housing developers. The approach recognises the importance of institutional structures in defining patterns of economic, environmental and social resilience and diverging responses to policy intervention.

\section{Comparative Analysis of Policy Instruments}

The following sections explore fiscal, financial and regulatory instruments implemented to ensure growth in the system and its resilience. The focus is on the most dynamic aspect of the system - the provision of new housing in Vienna, Amsterdam and Copenhagen.

\section{Fiscal and Financial Instruments}

In principle, affordability in the Austrian system is ensured by brick-and-mortar subsidies in the form of discounted land, public loans, grants and tax relief. Housing programmes, and the new supply of social housing, enjoy a relatively long-term stability and support from federal resources on the basis of housing policy commitments of the provinces (Länder). ${ }^{1}$ These are complemented by local grants to ensure adequate supply of new social housing. Vienna, with the status of a federal state, has a long-standing tradition of social housing provision, demonstrated in stable financial support. Typical financing of new social housing is based on a system of five interacting layers of low-interest, long-term commercial loans (50-70\%), subsidies (grants, lowcost loans) (20-60\%), equity contributions by developers (5-15\%) and future tenants $(0-10 \%)$ (Mundt and Amann, 2019). Loan repayments ensure revolving funds at the provincial and nonprofit association levels. To enable low borrowing rates for commercial loans and to channel private investment in to new social housing development, housing banks (Wohnbaubanken), which are subsidiaries of the five major commercial banks, offer tax-privileged housing construction bonds to housing providers. Purchasers of the bonds are required to hold them for ten to 15 years, and, in return, capital income tax relief is offered on the first $4 \%$ of investment returns. 
The system contributes to stabilisation of the housing market and lowers borrowing costs. The annual city budget for direct subsidies (new construction and renovation) has fluctuated between $€ 505$ million and $€ 735$ million since 1997. Fiscal austerity measures since 2009 affected these allocations and reduced the output of new social housing by Limited Profit Housing Associations (LPHA).

In the Netherlands, the Dutch government abolished the supply-side subsidies in 1993 and promoted a more enabling and financially self-sufficient approach to social housing provision. Within this framework, housing associations are free to sell, invest and choose the way to allocate their revolving funds to fulfil their social mandate. Housing associations finance new social housing with capital market loans, own equity and revenue from sales of newly built housing and/or sale of rental dwellings. Commercial loans are guaranteed by the national Social Housing Guarantee Fund, which reduces the capital costs (van Kempen and Priemus, 2002). In the last few years, policy changes have attempted to redefine 'social housing'. An income limit was placed on social housing units, requiring housing associations to provide $90 \%$ of their housing stock to households with taxable income of $€ 33,000$ or less. These changes resulted in increased capital pressure on the housing associations, as capital from private market development after the start of the financial crisis became more restricted, coupled with a new government requirement introducing corporate taxation. While both measures further decreased available funds, the City of Amsterdam, which owns $80 \%$ of the land, continued to subsidise the provision of new social housing through reduced land lease fees on City-owned land (about 50\% lower compared to regular market developments).

Danish housing policies have gone through a phase of retrenchment, gradually transitioning from support to housing supply to demand-based subsidies to households (Nielsen, 2010). The social housing sector is subsidised through central government co-payment of the interest rates on mortgages financing construction of new dwellings. Other supply-side subsidies are also provided through the urban renewal programmes and interest-free loan for capital costs by local governments. Social housing is exempt from income tax and real-estate tax. A reform in the financial system in 2002 introduced an increased degree of self-financing for housing associations and an obligation to reimburse more than half of total state subsidies for new social housing. The cost of new social housing provision (91\%) is financed by a mortgage (30-year variablerate loan) by Landsbyggefonden, an independent organisation established in 1967 by non-profit housing associations. It guarantees mortgage loans in collaboration with the municipality. The municipality covers $7 \%$ in the form of an interest-free loan for base capital (grundkapitallan), while the remaining 2\% is covered by tenants' deposits (Scanlon and Vestergaard, 2007; Tsenkova and Vestegaard, 2011).

In the three countries, low-income tenants receive demand assistance to defray housing costs. In the Netherlands, an income limit is applied when allocating new housing. At least $90 \%$ of the rental housing with a rent below the maximum rental supply limit ( $€ 648$ in 2009 , €711 in 2015) must be allocated to households with an income up to $€ 33,000$ (€35,000 in 2015). This means that more than $40 \%$ of Dutch households qualify for social housing. In Austria, demand assistance is not a dominant feature of the social housing system, and its expansion has been resisted by the sector (Mundt and Amann, 2019). It is estimated that $60 \%$ of all Viennese households live in subsidised housing (municipal, non-profit and private rental). Although the crisis has created pressures in the system increasing the share of households receiving demandbased support, it starts from a very low base of 3\%. Housing allowances have a broad coverage in Denmark and are granted to more than 530,000 housing in the social and private rental housing, equivalent to more than one-fifth of all Danish households. There are two main housing allowance schemes: (i) for low-income households and persons receiving disability pension, and 
(ii) for old age pensioners (Nielsen, 2010). Data indicate that housing allowances make up 50\% of the rent in social housing in general and in the case of newly built projects, $55 \%$ (Interview data, June 2013).

\section{Regulatory Instruments}

In Austria, a wide range of regulatory instruments ensures the supervision of social housing providers and defines their allocation and rent-setting policies. LPHA operate on a cost recovery basis and needs to keep separate accounting for each project. Profits are capped at $6 \%$ and need to be reinvested in the housing portfolio. Regulations specify the conditions, which must be met in order to receive subsidies (cost, size of dwellings and target households) (Bauer, 2004). Supply-side subsidies finance about $30 \%$ of development costs (land and construction). City Council supports new social housing through the provision of land by Vienna's Land procurement and Urban Renewal Fund - Wohnfond - a non-profit financially independent land banking and development organisation preparing sites for social housing development since 1984. As a way to reduce construction costs, encourage high-quality and innovative design and achieve energy-efficiency targets, the City of Vienna introduced compulsory tender procedures and mandatory developer competitions for developments larger than 200 units. Proposed development plans are judged by a panel on the basis of quality, cost, energy efficiency and social sustainability. Approved proposals are granted subsidies and land by the City (Förster and Menking, 2019).

In most of the cases, new housing requires a contribution from tenants in the range of $10 \%$ of development costs. Since 1993, national regulation introduced 'the right to buy option', which enables tenants to purchase their dwellings after ten years in cases of such contributions. It is unclear how 'the right to buy model' will affect the sector in the future. Rents are calculated on a cost-rent basis in accordance with Limited Profit Housing Act. The Act establishes maximum and minimum allowable rent to cover the cost of land acquisition, construction, capital costs of the project, administration and investment in maintenance. Initial rents can be increased each year with the consumer price index (CPI), and revenues should be sufficient to repay the annuity of the capital loan as well as the interest on the public loan.

In the Netherlands, the supervision is less prescriptive, and housing associations are supervised on the basis of general 'fields of performance' (Boelhouwer et al., 2006). They are driven by portfolio management considerations and operate in a more business-like manner. Given their financial self-reliance, housing associations in Amsterdam sell existing housing (2 for 1 rule) to build new housing and reinvest profits and own equity to ensure a tenure and social mix in new projects. Sales as well as levels of new social housing provision in Amsterdam are subject to negotiation with the City administration and specified in three-year agreements, but both sales and new social housing output have failed to meet recent targets (Amsterdamse Federatie van Woningcorporaties, 2010). Housing associations are required to give priority to accommodating low-income and disadvantaged households, but are also driven by considerations of balancing revenue and expenditures. In Amsterdam, the allocations are centrally managed by the municipality, with over 100,000 households registered in the system. The implementation of the 'Delft model' allows prospective tenants to react on vacancies published every two weeks (Gruis et al., 2005). Specific rules apply to determine eligibility for relatively cheaper social rented homes (rent under $€ 548$ per month as of July 2009). In terms of rent-setting, social landlords have the freedom to pool rents across their portfolio and address priority tasks. This autonomy, however, is confined by rent regulations defining rents by the central government with prescriptive annual rent increases, usually adjusted by CPI (van der Veer and Schuiling, 2005). 
In Denmark, municipalities supervise the housing associations and, since 1994, must approve their decisions for investment in new housing, which implies a financial commitment of $7 \%$ to capital costs. Each of the 7,750 housing estates (or 'member sections' in Danish) must balance its books - there is not supposed to be any cross-subsidisation between housing associations, or between estates that belong to the same association. The municipalities approve housing associations' budgets and accounts (Jensen, 2013). In 2004, an attempt to privatise social housing essentially delivered limited results. Out of the 5,000 apartments, fewer than 800 have been privatised, and this figure for Copenhagen is lower than 70 (Interview data, June 2010). The boards of tenants generally oppose privatisation, and tenants have been reluctant to take on such risks, despite a 30\% discount of the market price. Social housing must be rented on cost recovery principles. The rent is expected to cover the cost of development (based on mortgage repayment costs) as well as maintenance and management charges. The average rents are 600$700 \mathrm{DKK} / \mathrm{m}^{2}$ in estates/sections constructed before 1920 , falling to $515 \mathrm{DKK} / \mathrm{m}^{2}$ in estates constructed in 1960-1964 and then increasing to over $750 \mathrm{DKK} / \mathrm{m}^{2}$ in the most recent estates. ${ }^{2}$ Access is managed by housing associations on the basis of time on the waiting list and household size. There are no restrictions on who may join a waiting list, and the social housing sector is open to all income groups. Municipalities have the right to assign tenants to at least $25 \%$ of vacant housing association units. Waiting times in Copenhagen in attractive older estates exceed 15 years, but new housing due to its higher cost may be readily available (Interview data, June 2010).

\section{Social Housing System Responses: Patterns of Resilience}

\section{Partnerships and Institutional Resilience}

Social housing systems are path-dependent, so it is important to position the patterns of institutional transformation in the context of outcomes attributed to past housing policies and market conditions affecting the start of the crisis. The tenure distribution and the relative share of social housing operated by major providers/institutions in 2009 are important starting points. Data in Table 13.1 indicate that social housing was dominant in Amsterdam (50\%) and Vienna (44\%), but it also accounted for a sizeable share of the housing stock in Copenhagen.

Social housing in Austria is developed and owned by LPHA. The institutional ownership could be municipal, cooperative or private. There were more than 190 LPHA owning about $22.5 \%$ of housing in Austria and 20\% in Vienna in 2009. The City of Vienna owned another 24\%, while owner-occupied housing, mostly apartments, constituted 19\% (see Table 13.1). In the Netherlands, social housing is managed by private non-profit housing associations

TABLE 13.1 Housing Tenure in Vienna, Amsterdam, and Copenhagen, 2009

\begin{tabular}{lccc}
\hline Housing Tenure Share of Total Housing & Vienna (\%) & Amsterdam (\%) & Copenhagen (\%) \\
\hline Social (non-profit) housing & 20 & 50 & 16 \\
Social (municipal) housing & 24 & & \\
Private rental housing & 36 & 24 & 21 \\
Owner-occupied housing & 19 & 26 & 31 \\
Cooperative housing & 1 & & 7 \\
Other housing & 100 & 100 & 100 \\
Total & & & 25 \\
\hline
\end{tabular}

Source: Interview data, 2011. 
operating under a range of public regulations for over 100 years. The social landlords owned $35 \%$ of the total stock in the Netherlands and 50\% in Amsterdam in 2009. Private renting in the city was less significant compared to Vienna and accounted for $24 \%$ of the housing stock, but rent-setting and demand-based subsidies are applied in a tenure-neutral way to social and private rental. The financial reforms in the last 20 years have resulted in a large number of mergers reducing the number of housing associations from 767 in 1997 to 492 in 2005, with only seven operating in Amsterdam in 2010 (Amsterdamse Federatie van Woningcorporaties, 2010).

The Danish social housing sector (almene boliger) comprises housing owned by non-profit housing associations ( $20 \%$ of total housing stock) and a small amount of public stock (about $2 \%$ ), mostly used for short-term emergency housing. There were about 760 housing associations, which own 7,750 estates with 541,500 dwellings (Ministry of Wefare, 2009). The associations are self-governing units and the dwellings are not entirely public nor privately owned, hence the concept of third-sector housing. The tenants are organised through a model of internal democracy, which ensures that there are representatives from the tenants parallel to the administrative levels within the sector. In Copenhagen, the share of social housing was $16 \%$ managed by 28 housing associations. All sectors, including private rental, social and cooperative housing, are subject to rent regulation.

With the external economic shocks experienced by all European countries since 2008, tightening of mortgage lending and fiscal austerity measures, the investment in the housing in general has declined, but the impact on the social housing sector has been particularly significant (CECODHAS, 2012; Scanlon et al., 2015). The private limited profit associations in Vienna and the housing associations in Amsterdam are extremely professional, knowledgeable and able to withstand stresses and to adapt to sudden shocks. While they contained the effects of financial and fiscal stress during the times of crisis, there were significant disruptions to their portfolio and ability to continue to invest in new high-quality affordable housing. Social housing providers in both cities enhanced their efficiency through mergers and acquisitions of smaller associations to optimise asset management and consolidate properties across different portfolios. Redundancy was not a viable strategy (Interview Data, 2013). These private market agents are very resourceful in navigating the system of finance, development control and planning regulations, but due to the capital-intensive nature of new social housing provision, their ability to mobilise resources (financial, technical, physical) to counteract disruption was system-dependent. In Amsterdam, the lack of supply-side support resulted in a shrinking portfolio reaching $47 \%$ of total housing in 2013, while in Vienna due to a more limited but still ongoing flow of subsidies, the share social housing has grown to $23 \%$.

In Copenhagen, the third-sector model was more vulnerable to market fluctuations in capital and mortgage markets, affecting the ability to mobilise funds for new social housing provision. However, more proactive City strategies to assist with access to low-cost land and ability to acquire projects from bankrupt private housing developers provided a small boost to a sector that for years was struggling to deliver new affordable housing due to high costs. In the financial crisis period, a public-private partnership (PPP) model for a new type of affordable housing (Almenbolig) with a tenure-mix strategy appeared in Copenhagen. The goal of these partnerships is a mixed neighbourhood where non-profit housing associations collaborate with cooperatives and private developers to deliver new housing, often on brownfield sites. On the development side, housing associations are represented by six very professional organisations well versed in the planning and construction management process. Despite these positive shifts, data indicate that the share of non-profit housing in Copenhagen declined by $0.7 \%$, while private rental increased (Ministry of Housing, Urban and Rural Affairs, 2013). 
Overall, the institutional transformation has responded to three similar drivers: state/ provincial decline of subsidies to social housing production, collaboration with private sector to finance new housing while increasing the role of public/private partnerships and, finally, growing authority of municipalities/cities. The partnerships were embedded in the provision system of Vienna and Amsterdam for decades, but are relatively new in Copenhagen. The three European cities have joined their efforts with non-profit and private organisations to provide social housing in mixed-income, mixed-tenure projects. A model of public, private and not-for-profit (PPNP) partnerships has evolved over time, capitalising on the strengths of each sector. The public sector (federal, provincial, municipal) is effective in the mobilisation of much-needed resources, while the private sector (designers, developers, construction companies) is efficient in managing the construction process by maximising economies of scale, tapping into technological innovation and marketing strategies. Not-for-profit housing institutions are more effective in managing and operating social housing due to the extensive knowledge of the people they service. In large-scale developments, such synergies are important in the provision process (design, build, finance, operate), as insights from projects in Vienna, Amsterdam and Copenhagen demonstrate. In Vienna and Amsterdam, these partnerships are led by the social housing providers-private organisations-operating with a high degree of efficiency and autonomy to design-build-finance-manage/operate social housing. They have a strong legacy and significant institutional resilience, which is a real strength of the sector.

\section{Economic and Environmental Resilience}

The overall restructuring of the social housing systems in economic terms implies that the institutions are able to minimise economic and social losses during a crisis to allow moderate growth in the system. It can be achieved by the ability of a social provider to perform more efficiently and effectively to absorb a shock, and to recover quickly without compromising affordability and quality. As the focus is on the most dynamic component of the system, the comparative analysis in this section highlights important similarities and differences in two areas: output/ investment and strategies to develop new social housing at the city level. The projects illustrate important aspects of environmental resilience in terms of location, design qualities and environmental characteristics to enhance energy/water performance.

Housing production levels in Vienna have been relatively stable since 2003, with a peak in 2007 due to a growing share of social rental housing with the option to buy. Supply subsidies in Vienna declined sharply in 2000, reducing production from 12,000 to 6,000 dwellings under the conservative coalition government, but output increased to 9,000 dwellings in 2007. LPHA accounted roughly for half of the new production in the city. The impact of the financial crisis on output was significant in 2011, but later trends stabilised (see Figure 13.2).

The City of Vienna is actively steering the production of new housing into areas of brownfield development and other secondary nodes in support of its planning and urban development priorities. The City also operates an evaluation system to rank projects for new sites sold through Wohnfond. Land is sold by competitive tender, which aims to reduce building costs and focuses developers on quality outcomes (Förster and Menking, 2019). In the redevelopment of brownfield sites (Gasometer, Kabelwerk), the social housing providers establish joint companies with private developers to meet City's requirements of mixed-tenure, mixed-income communities (Figure 13.3). Kabelwerk, a former industrial factory, was reinvented as a new neighbourhood with 950 dwellings, with a mix of social rental and owner-occupied housing, shopping, offices, kindergarten, green spaces and cultural facilities (Tsenkova, 2014). In other strategic urban regeneration sites, such as the new quarters along the Danube River, LPHA 


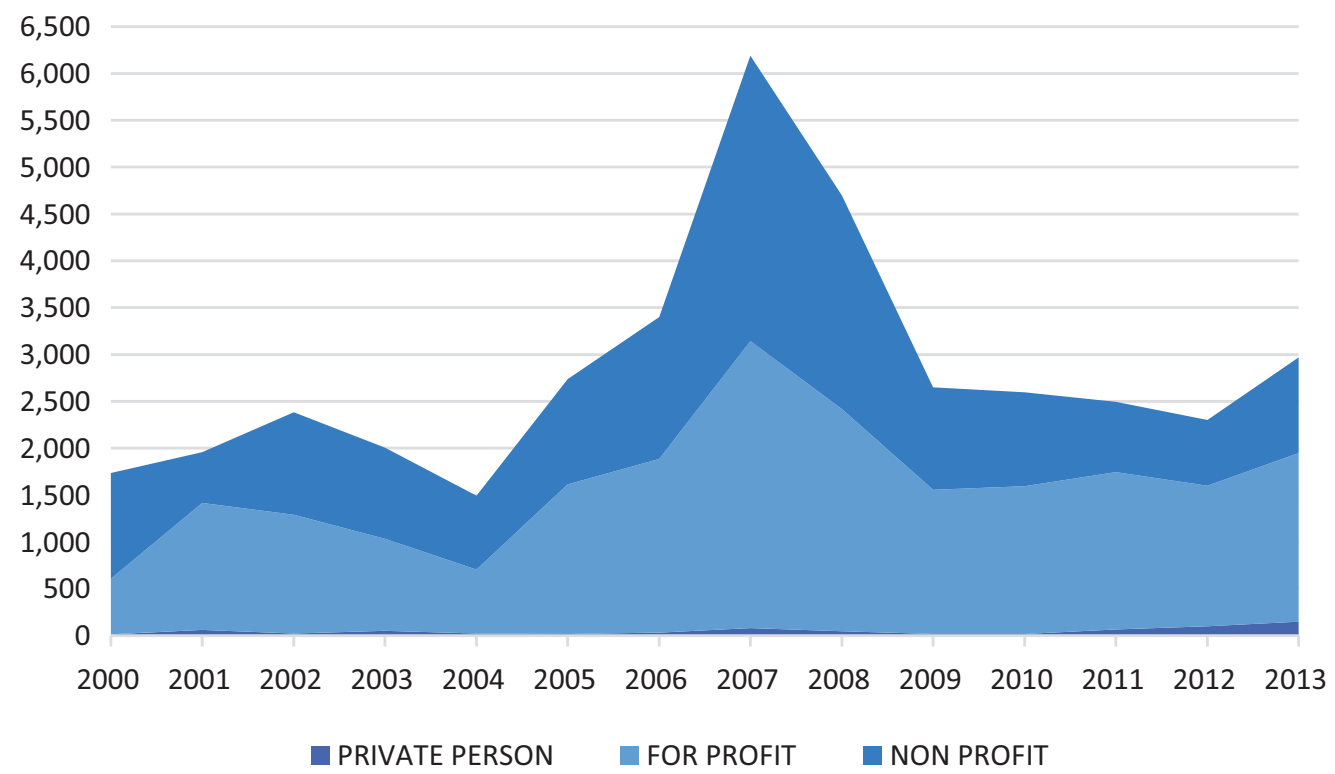

FIGURE 13.2 New Housing Construction in Vienna and Amsterdam, 2001-2013.

Source: Author's estimates based on data from Austrian Federation of Limited-Profit Housing Associations (GBV); Centraal bureau voor de Statistiek, 2013 (statline.cbs.nl/StatWeb/publication); Ministry of Housing, Urban and Rural Affairs (n.d.); the Danish social housing sector (www.mbbl.dk/sites/mbblv2.omega.oitudv. dk/files/dokumenter/publikationer/the_danish_social_housing_sector.pdf).
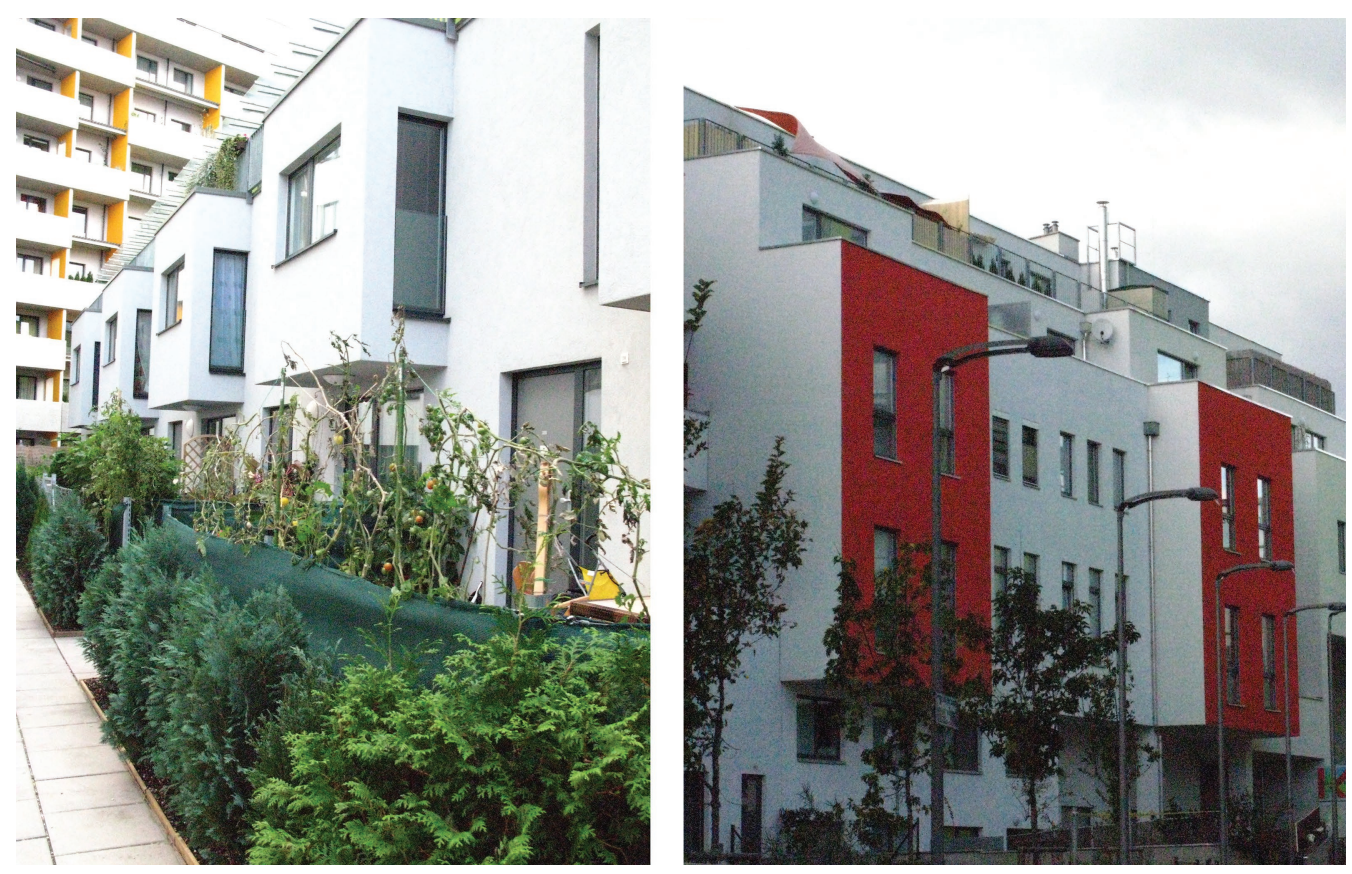

FIGURE 13.3 Brownfield Developments in Kabelwerk, Vienna.

Source: Sasha Tsenkova. 

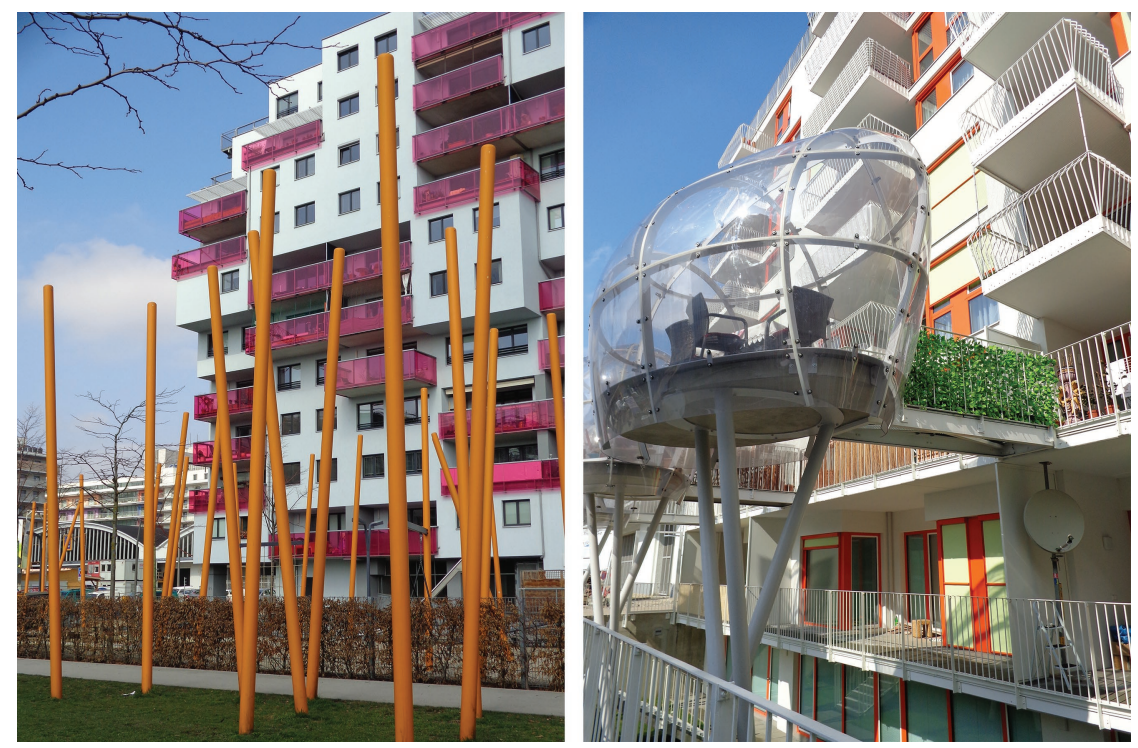

FIGURE 13.4 Mixed-Income Housing in Urban Regeneration Quarter in Vienna.

Source: Sasha Tsenkova.

built new social housing in developments with high-quality services, schools, public amenities and transit to initiate the process of neighbourhood rebuilding (see Figure 13.4). Due to the mixed-income, mixed-tenure models, it is not possible to distinguish social housing from the other housing developments. In terms of business strategy, when LPHA reach a critical mass of investment in the local area, private developers follow with market housing that may be more conservative in terms of design and quality.

There are many examples of innovative sustainable housing, passive housing, car-free developments and ethnic integration through design innovation fostered by the City's competitive bidding process and sustainable development guidelines for project evaluation. Eurogate is the world's largest passive housing development, with 2,000 flats achieving energy demands between 7 and $15 \mathrm{kWh} / \mathrm{m}^{2}$. Through solar orientation and technology that improves exterior wall and window insulation and air supply, the energy-efficient design contributes to the reduction of carbon emissions, as well as to lower heating costs for residents. Located in Aspang-Gründe on a 20 ha former railway area, the development involves six different property developers and seven different architects, who were awarded the right to build and the supply-side subsidies through City-administered developer competitions. The development accommodates about 5,000 residents and 8,300 jobs (Förster and Menking, 2019).

Nordbahnhof is a residential complex located in Vienna, constructed with prefabricated concrete; the building is lifted above the service facilities to offer covered exterior open spaces on the ground level that are connected to site amenities such as walkways and green spaces. Designed by Synn Architekten, the concept behind the development is based on providing units that are affordable, flexible and offer functional interior and exterior spaces for communication. The development includes mini-lofts (one- or two-room units) and one- or two- room family units with a flexible open concept design that can be modified based on the needs of the resident.

In Amsterdam, contrary to Vienna, the production by housing associations has tripled since 2000 , reaching 3,045 in 2007, but about a half or more is geared to the homeownership market 
(see Figure 13.2). Recent years have seen a wave of mergers and acquisitions of housing associations driven by risk reduction and portfolio management strategies. Housing associations focus on better quality of services, efficiency gains and neighbourhoods where they have a dominant position. New social housing is built on brownfield sites, and in the new greenfield development of Ijberg on land reclaimed from the sea (Gilderbloom et al., 2009). Production levels in 2007 reportedly responded to high pent-up demand for new ownership housing. The output of housing associations in the city accounts for $40 \%$ of the completions, which are in the range of 1,$200-1,700$ in the last five years. Social housing for rent—about $25-30 \%$ of this output - is used to achieve social and tenure mix in priority development areas for the housing associations, with $70 \%$ of the housing targeting the homeownership market and $30 \%$ retained as social housing. This is also perceived to be a revenue neutral model in terms of development costs. The impact of the financial crisis was significant, but levels of production bounced back in 2013.

Housing associations in Amsterdam have the historical role of city builders with increasing responsibilities to improve liveability of deprived neighbourhoods as well as to provide social infrastructure. The sale of social housing is encouraged by the municipal administration in order to create more tenure choices and attract middle-class families to the city. Overrepresentation of social rented housing in some parts of Amsterdam is perceived to contribute to the concentration of socio-economic problems and ethnic minorities (Van der Veer and Schuiling, 2005). In these neighbourhoods, such as the New West, housing associations created strategic partnerships to demolish parts of the social housing and develop new medium-density, tenuremixed communities (Amsterdamse Federatie van Woningcorporaties, 2010).

The New West in Amsterdam is an example of a housing estate built in post-war years where 10,000 social housing apartments, mostly home to low-income ethnic communities, were subject to major energy-efficiency retrofits to improve the environmental performance and the quality of housing. Other major improvements to the neighbourhood focused on high-quality public spaces, urban playgrounds, provision of local work opportunities and new housing (see Figure 13.5). In the process of social engineering of the neighbourhood, a consortium of housing associations demolished 3,000 social housing units, provided 5,500 new private housing apartments and sold about 1,600 social housing units to tenants under very favourable financial conditions. This transformation from 2009 to 2015 is impressive in social and economic terms:

- Social housing: from $75 \%$ to $45 \%$

- Market rental housing: from $10 \%$ to $15 \%$

- Privately owned housing: from $15 \%$ to $40 \%$.

(Tsenkova, New West Project office Interview, 2013)

Housing associations have taken the lead in the redevelopment of Amsterdam's Docklands. These brownfield sites are centrally located, with access to water amenities and transit. The process is part of a long-term planning strategy for sustainable regeneration of Amsterdam using a model of integrated jobs, retail, community facilities and green + blue recreation with a mix of social, market rental and ownership housing. In many cases, the design strategy includes the adaptive reuse of industrial heritage reinvented as mixed-use hubs to encourage social interaction between residents (see Figure 13.6).

The new development strategies by housing associations in Amsterdam pioneer a lot of design innovation, often the outcome of architectural competitions run by the large associations. The implementation of sustainability by design is systematic, in addition to newly adopted codesign approaches to facilitate the integration of tenants and owners in one building and complex. The new projects in Ijburg demonstrate these outcomes. Located about $10 \mathrm{~km}$ east of the 

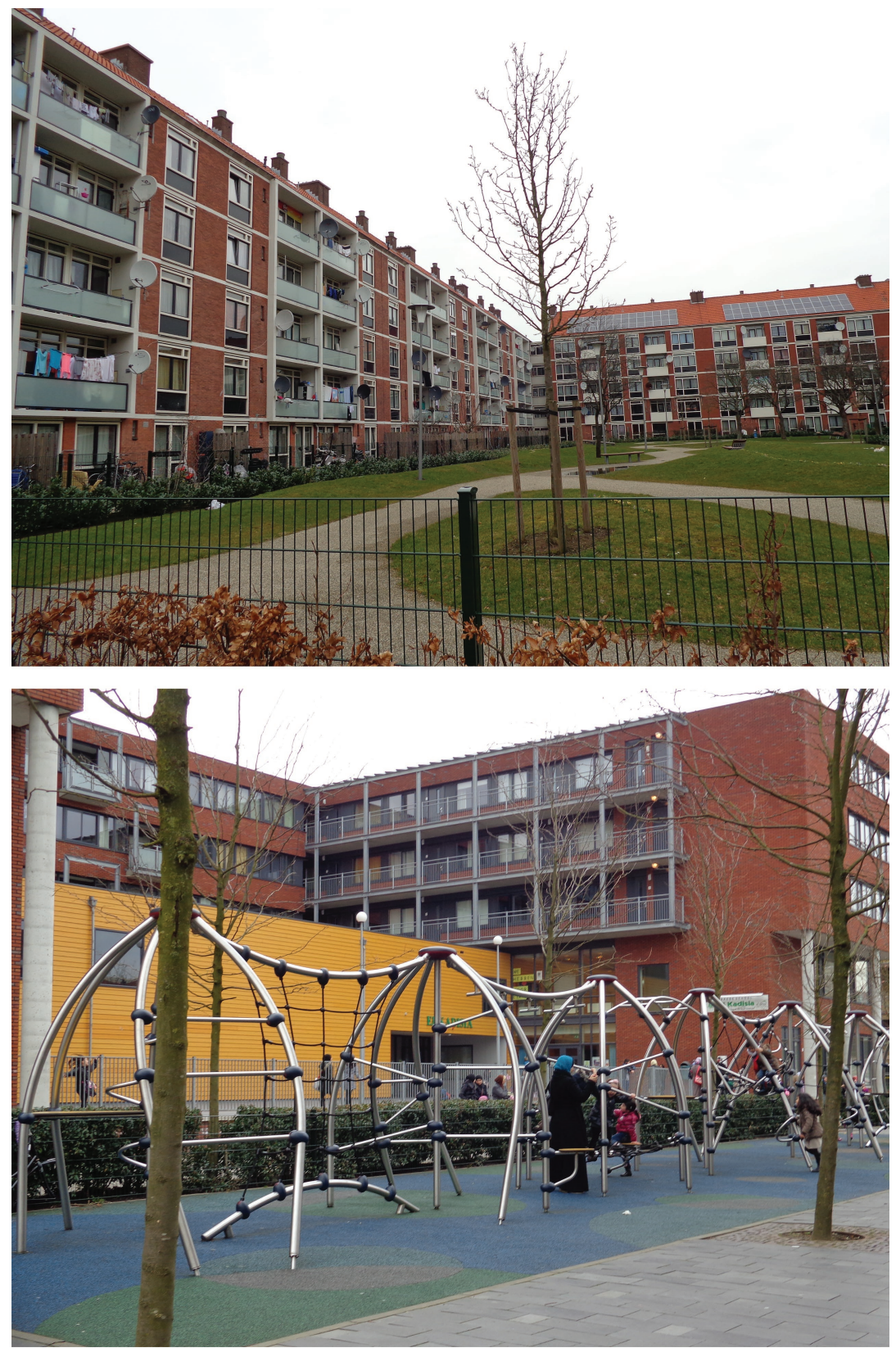

FIGURE 13.5 Redevelopment of the New West in Amsterdam.

Source: Sasha Tsenkova.

city of Amsterdam, Ijburg is an archipelago of artificial islands planned to have 18,000 homes. After the completion of the first three islands, Ijburg included 30\% social housing integrated in the community, with 15\% designated as 'very low rent' (Gilderbloom et al., 2009). Planners emphasised social integration that has seen the mix of all housing tenure types within individual blocks, and even within buildings, all with little differentiation between the units. The incorporation of mixed incomes throughout the community facilitates the use of common space by all households and prevents the segregation of certain groups (Buitelaar and De Kam, 2011). 

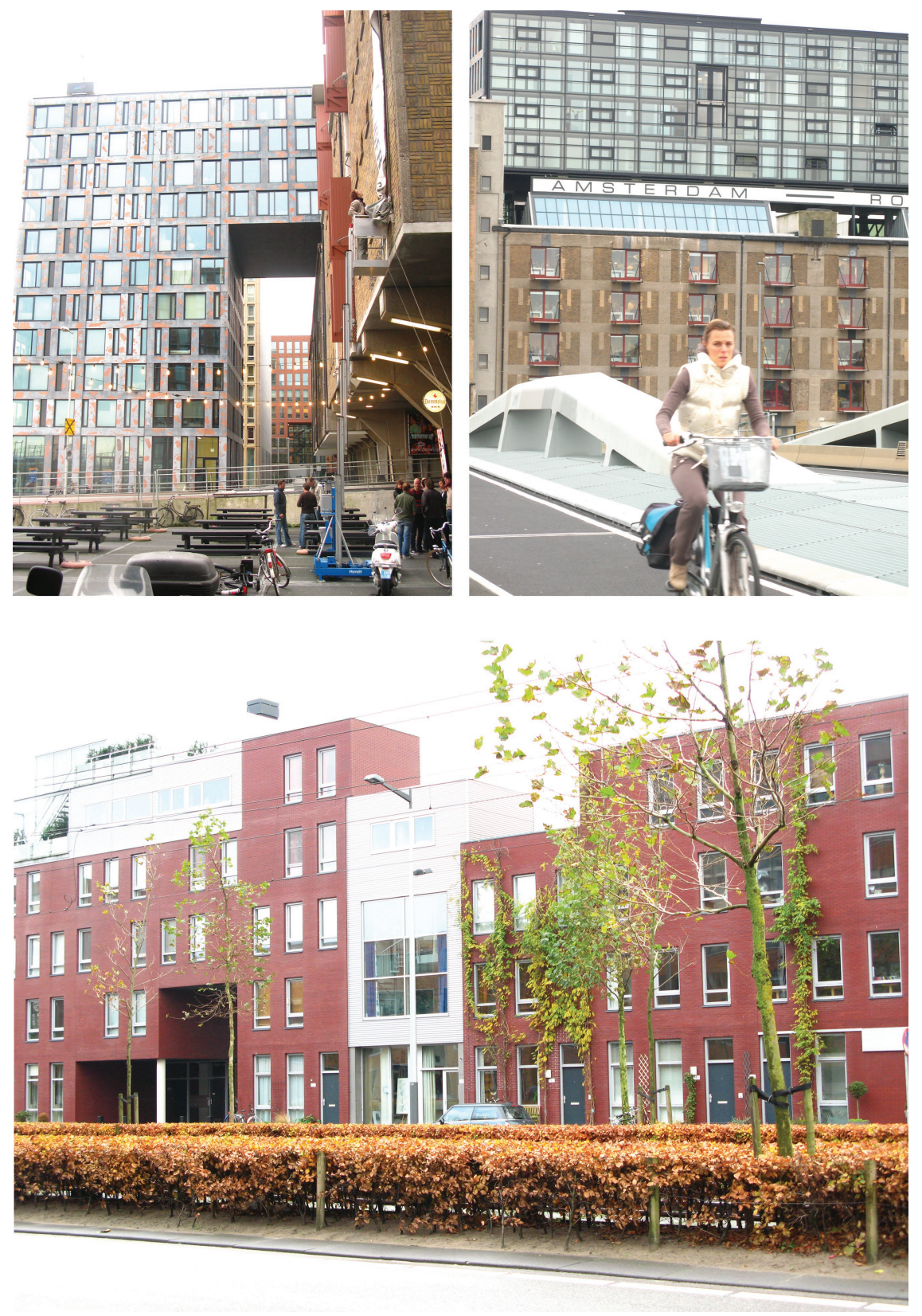

FIGURE 13.6 New Mixed-Income Housing Development in the Amsterdam Docklands and Ijburg. Source: Sasha Tsenkova.

In Denmark, levels of new social housing output declined dramatically since 2006 as a result of a policy changes reducing subsidies to housing associations and emphasising a higher degree of self-reliance (see Tsenkova and Vestegaard, 2011). In Copenhagen, the decline in output was exacerbated by high construction costs and growing land prices related to the housebuilding boom in the owner-occupied market. An important factor affecting the supply of social housing was the regulatory cap on construction costs introduced in 2004. The limits increased steadily and reached DKK 20,710 for family housing and DKK 25,710 for seniors in 2010, but these 
limits exceeded the costs in Copenhagen. Despite some regional variation of such costs, the central regulations affect substantially where housing associations can build, and how much. Given the high land prices in Copenhagen, this led to a collapse in new social housing provision in the mid-2000. The global financial crisis provided some opportunities to invest and expand the sector due to availability of land, acquisition of housing projects (private sector developers under bankruptcy) and overall stability of financing for social housing, but the output per year was limited and even non-existent in 2009 and 2010 (Interview data, June 2010).

City policies set targets for social housing output for the 2009-2013 period: 700 flats for families and 200 homes for the disabled. ${ }^{3}$ The City's investment in total amounted to 120 million DKK (interview data, June 2010). The City of Copenhagen announces annual competitions to reach its target for new social housing construction. The six largest administrative organisations managing the social housing portfolio of the housing associations compete on the basis of quality, innovative design, sustainable features and energy-efficient solutions (such as passive housing, 'zero' energy housing). In the financial crisis period, a local PPP for a new type of affordable housing production (Almenbolig) with a tenure-mix strategy emerged in Copenhagen. The Emiljhaven project brought together non-profit, cooperative and private developers to build 193 units. Compared to Vienna and Amsterdam, completions of new social housing were modest, in the range of 150-200 dwellings per year (less than $0.5 \%$ growth in the existing portfolio). During the post-financial crisis period, the City approved four to five projects on an annual basis and channelled some of these investments into urban regeneration areas such as the old Copenhagen harbour (see Figure 13.7).

Sluseholmen is a residential area in the Copenhagen harbour with 1,800 apartments on eight islands. The design is inspired by the Dutch city model with canals running between the blocks with interconnected courtyards. A leading principle in the development was to create a coherent area with a lot of diversity and unique identity for each island. Twenty-five different architectural firms were involved in the design. The developments have a mix of uses and a diversity of housing and tenure types, range from four to seven storeys, depending on whether they face the harbour, the promenade or the canals. Units have a central heating system and local amenities-bicycle pathways, water features and generous public spaces. Another innovation to increase the supply of social housing was associated with the provision of prefabricated housing. A Non-profit Fund for Cheap Housing was created to ordered 800 modular, prefabricated units from Estonia, where they could be built for 30-40\% less; another 7,200 prefabricated units were delivered by producers in Sweden, Norway and Denmark (Figure 13.7). Only 5,000 of the 8,000 units were designated as low-rent housing (Scanlon and Vestegaard, 2007).

\section{Social Resilience}

The social resilience of the social housing systems implies that it retains its ability to deliver high-quality affordable housing with a fair amount of choice to tenants. This is associated with costs of new housing, the flow of services it provides in terms of access to transit, neighbourhood amenities and social integration. The comparative analysis focuses on rents in new social housing, allocation processes and affordability constraints reflected in the share of households needing housing allowances to support rental payments. The insights from projects illustrate the path-dependent nature of the system and the fact that social resilience during the time of crisis is highly dependent on policies and wider regulatory aspects affecting the ability of housing providers to influence affordability and choice.

Average housing costs in LPHA housing in Austria are lower compared to those in the Netherlands and Denmark. The sector also has a much lower share of low-income households. 

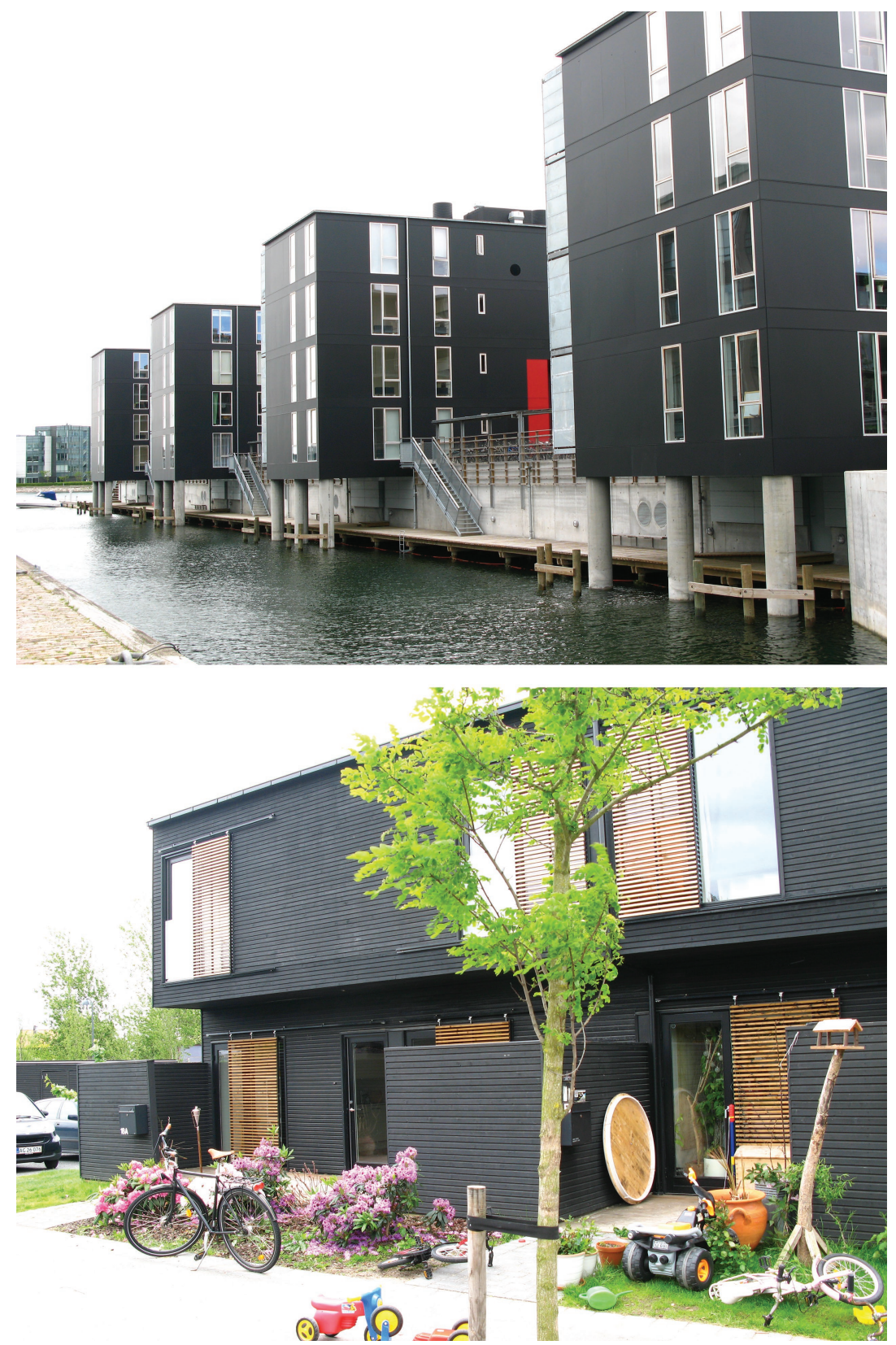

FIGURE 13.7 New Social Housing in Sluseholmen and Prefabricated Units in Copenhagen Central Areas.

Source: Sasha Tsenkova.

These characteristics of the national system have implications for the affordability of social housing in the capital cities. With income limits high enough to accommodate $80-90 \%$ of the population, access to social housing in Austria is more universal in comparison to many other European countries. While eligibility rules are defined at the federal level, housing providers are responsible for assessing eligibility and allocation of units. Social housing is not limited to low-income households, and the supply-side subsidies have contributed to its affordability. 
Rents are regulated based on unit area and quality of accommodation and are cost-based. The average cost for rent in Vienna was $€ 452$ or $€ 6.45$ per square metre of useful floor space in 2012 (Statistics Austria, 2012). The financial crisis did not change these conditions, but it affected the ability of tenants to contribute $€ 15,000-€ 30,000$ as a downpayment to project costs in new social housing. Interviews with major social housing providers of new developments indicated that tenants were increasingly young and ethnically diverse; about a third were migrants from Central and Eastern Europe, the Middle East and Asia. Problems with non-payment were almost non-existent, and vacancies were below $1 \%{ }^{4}$ Less than $5 \%$ of the tenants received housing allowances.

By contrast, rents in the Netherlands are not cost-based but politically determined with little variation across locations within the city. The central government sets expenditure levels, eligibility criteria, rent-setting rules and annual rent increases. Social rents are set according to a 'formula rent' for each property, calculated on the relative value of the property, its size, energy efficiency and relative local income levels. The average monthly rent in the social housing sector in 2007 was $€ 398$. Subsequent regulations limited the maximum rent for social housing to $4.5 \%$ of the property's valuation, which translated into a maximum rent of $€ 664$ per month in 2012 (CBS Statistics Netherlands, 2012). Across the Netherlands, 15\% of the households living in social rented housing received housing allowances; in Amsterdam, this share exceeded 20\% in 2011, indicating the presence of a larger share of low-income and vulnerable households in the sector, compared to Vienna. While social and private rental housing are treated in a tenureneutral way in terms of policy support, private rental is less affordable. ${ }^{5}$

Paradoxically, social housing in Denmark is not necessarily synonymous with affordable provision. A recent response by the Minister of Social Affairs to the Parliamentary Standing Committee on Housing indicates that there are 59,000 affordable rental apartments in Copenhagen (rent of less than 4,000 DKK per month, average size $58 \mathrm{~m}^{2}$ ). Only 20,000 are social and 39,000 are private rental. High construction and land costs, as well as a less generous subsidy regime, make new social housing less attractive to prospective tenants. In Copenhagen, social housing administrators reported problems with leasing new schemes, particularly when costs go beyond DKK $25,000 / \mathrm{m}^{2}$.

In terms of choice and allocation, the target group in Austria is rather broad, and reportedly close to $80 \%$ of the households can qualify for access to new housing. Households without sufficient capital or unable to access commercial loans can apply for a public loan at zero interest rates to pay the required $10 \%$ contribution. In Vienna, $25 \%$ of tenants are nominated by the City's Housing Service, half are offered externally to prospective tenants on the waiting list and the rest to existing tenants. Waiting lists are managed by individual LPHA, but the average waiting period is less than one year. By contrast, the centrally managed allocation system in Amsterdam provides a one-stop shopping opportunity for households, but the waiting time to get into a desirable neighbourhood is reportedly over six to seven years. Households in areas subject to major renewal programmes and demolition have a priority to return to the area and/or receive dwellings in the neighbourhood of their choice. The waiting time is attributed to the relatively flat rent structures that do not take into account location. Some of the historic properties in the most attractive parts of old Amsterdam reportedly have rent levels three to four times lower compared to market rates, and the situation may be similar in the case of new infill social housing along the canals (Tsenkova, 2014).

In Copenhagen, housing associations manage their own waiting lists, and the waiting period can be as long as ten to 15 years. When tenants move in, they have to pay a deposit that corresponds to $2 \%$ of the original construction cost of their unit. Housing associations also operate internal waiting lists, so tenants can move up the housing ladder within a housing association, 
from an expensive dwelling to a cheaper and more attractive one, which may explain the high number of households on the waiting lists in the City of Copenhagen (estimated at over 150,000). Social housing used to be considered a tenure for all, and in general there is still no stigma attached to living in social housing.

\section{Discussion: Crisis and Opportunity}

The global housing finance crisis in 2008 has had dramatic and sustained impacts on people and housing systems throughout the world (Tsenkova, 2021). This research explores housing policy strategies in the post-crisis period, focusing on three European countries with unitary housing systems and a strong social housing sector. The conceptual framework provides important insights into the dynamic relationships between housing policies and patterns of resilience in three capital cities. Findings point out that despite similar challenges and pressures to cope with increasing production costs, different countries and cities made different policy choices. The diverging experiences are exarcerbated by the institutional set-up defining the system of social housing provision. The complex and interlinked crises in housing finance, public subsidies and housing markets leads to diverging coping strategies by social housing providers. The institutional resilience and the ability to capitalise on partnerships with public, private and not-for-profit organisations are considered as strength in Vienna and Amsterdam. The partnerships have an important legacy and define the robustness and the adjustment of business operations.

Better policy tools and alignment of fiscal, financial and regulatory instruments result in more robust institutional and economic performance (see Tsenkova, 2019 for discussion). The Dutch 'Revolving Fund Model' is an example of a financial model for social housing that can withstand global financial and regional policy pressures. The Guarantee Fund for Social Housing acts as a solidarity fund that enables housing associations to benefit from favourable conditions and interest rates on the open capital market. The triple guarantee of security has allowed housing associations to remain in strong financial position throughout the economic crisis. In Austria, long-term commercial loans provide most of the capital funding, supported by Wohnbaubanken and tax-privileged housing construction bonds to housing providers. In Copenhagen, housing finance is much more market-driven, leading to higher borrowing costs and lower output of new social housing.

While Austria retained its brick-and-mortar support for a strongly regulated limited profit, cost-capped and cost-rent regime, in the Netherlands the elimination of supply-side support has led to financial self-reliance, organisational change, sales and more entrepreneurial strategies by housing associations. Both systems demonstrate a high degree of economic resilience and are essential in pursuing national and city development objectives (neighbourhood renewal, brownfield redevelopment, sustainable practices). Dutch housing associations have a lot more freedom to pursue own policies in terms of new development, sales and other commercial activities. In Amsterdam, they dominate the market for new housing but produce predominantly for homeownership with significant exposure to market risks, which makes them more vulnerable during recessions when sales are not brisk and market prices are declining. This exposure to the fluctuations in the owner-occupied housing market makes the system more vulnerable to external shocks and places significant limits on innovation (Tsenkova, 2014). In Austria, the existence of public grants and loans influences production levels and shields the sector from market fluctuations, providing more stability for its operation. Although public finance has declined in proportion to other forms of investment, it remained essential as collateral for securing commercial loans. 
In terms of environmental resilience and ability to build new housing in mixed-income, mixed-tenure communities on priority urban sites, LPHA in Vienna perform better. Social housing landlords are extensively regulated through the cost-rent model and limitations on profits in Austria, while in the Netherlands the centrally determined rents provide stability in the rental market, but may constrain investment in innovation and quality improvements. Levels of output are influenced through voluntary agreements with Amsterdam municipality and below-market land leases, but have been in general lower compared to Vienna, resulting in net losses in the portfolio. In Vienna, new social housing pioneers design innovation, sustainable living and consistently deliver high standards, in part steered by the City of Vienna competitive bidding process for land allocation through the Wohnfond. This is not necessarily the case in Amsterdam, where housing associations claim that every new social dwelling results in a loss of over $€ 100,000$ for the organisation, with obvious limitations for such experiments. In both cities, partnerships are an important legacy of the system and an area of institutional strength.

The Danish system is less resilient in institutional and economic terms. Denmark has a different institutional model of third-sector social housing, owned by the tenants and serviced by professional administration responsible for new development and management of the existing stock. Danish housing policies have gone through a phase of retrenchment, transitioning from 'brick-and-mortar' support to demand-based support. The sector is also changing from providing affordable housing to all groups in society, towards a more selective role of provider for groups with special needs and the elderly. Finally, housing associations seem to be less influential, given the declining share of new output and limited growth prospects in Copenhagen. Although since 2011 new social housing construction has gained some momentum, production costs remain high and rent levels ensuring cost recovery tend to be highly dependent on demand-based support through housing allowances.

In terms of social resilience, affordability and choice are much more significant in Vienna, manifested in shorter waiting lists (less than two years, compared to seven in Amsterdam) and a much lower dependence on housing allowances to pay cost recovery/controlled rents. In all, 5\% of tenants in Vienna receive housing allowances versus over 30\% in Amsterdam, although the required tenant contribution may present a barrier for some socially vulnerable groups. Access to social housing is universally accessible, while in Amsterdam some income limits steer the allocation to low- and mid-income housing. In Copenhagen, despite the high quality of new social housing, due to its high costs, this is not a preferred choice and in some cases it is difficult to rent.

\section{Concluding Comments}

The three cities have a strong system of social housing provision that responds to similar pressure in the post-crisis period: decline in public finance due to austerity measures and growing shortage of affordable housing in local markets. Patterns of institutional resilience indicate a move towards more self-reliance, entrepreneurial strategies and partnerships for the provision of new social housing. Social housing plays a critical role in Amsterdam and in Vienna and has a long history of support instruments to ensure its stability in city building. While direct government subsidies have declined, the role of cities has grown (Tsenkova, 2021). Cities and planning play an important role in regulating the supply of new social housing through inclusionary zoning, provision of land and design control. All three cities provide excellent examples of mixed-income, mixed-tenure neighbourhoods with emphasis on sustainable design and high environmental performance. On the social side, rent control and housing allowances ensure 
opportunities for social integration and stability in the social rental sector, so social housing provision can bounce back and recover from the external shocks.

As cities recover from the biggest health and economic crisis the world has collectively ever faced, the resilience of social housing systems will be extremely important. The crisis has exposed major gaps and inequalities in urban housing markets, particularly for low-income households. As we chart the road to recovery, we can learn from the success of other cities where better housing policy leads to a more resilient performance with better results for local communities. This is the time to invest in better tools and work towards building a more effective, equitable and more robust social housing response system.

\section{Acknowledgement}

The research is supported by the Social Sciences and Humanities Research Council of Canada.

\section{Notes}

1 The level of subsidization in Austria is high in comparison to other European countries with 80\% of housing receiving subsidies. Direct expenditures by provincial governments, which amounted to $0.9 \%$ of Austria's GDP in 2010, included subsidies for new construction (60\%), building refurbishments (25\%) and allowances (14\%) (Interview data, 2012).

2 The average exchange rate in 2010 for 1 Danish krone (DKK) was $€ 0.1344$.

3 This was still short of a target set by Copenhagen's mayor elected in 2006 on a promise of providing 5,000 new homes at a rent of DKK 5,000 (approximately €670) per month. It was clear that housing associations could not build these homes since the building standards they must comply with are so costly that rents would necessarily be much higher.

4 In 2007, the average rent burden in Vienna, across both private and limited profit sector, for couples with children was only $20 \%$ of household income (Czasny and Bständig, 2008), which is considered low compared to other European capital cities.

5 Tenants are spending a larger proportion of their income on housing - up from 34\% in 2009 to $38 \%$ in 2018; social housing rents have gone up $26 \%$ over the past ten years, rents in the non-rent-controlled sector have risen $44 \%$.

\section{References}

Amann, W., Lawson, J., and Mundt, A. (2009) Structured Finance Allows for Affordable Housing in Austria, Housing Finance International, July, pp. 14-18.

Amsterdamse Federatie van Woningcorporaties (2010) Jaarboek 2010. Amsterdam.

Angel, Sh. (2000) Housing Policy Matters-A Global Analysis. New York: Oxford University Press.

Austrian Federation of Limited-Profit Housing Associations-Audit Federation (GBV) (2013) Organization Summary. Vienna: GBV. Retrieved February 28, 2012 from www.gbv.at/Document/View/4104

Bardhan, A., Edelstein, R., and Kroll, C. (2012) Global Housing Markets. Crises, Policies and Institutions. Hoboken, NJ: Wiley \& Sons.

Bauer, E. (2004) Austria. In V. Gruis and N. Nieboer (eds)., Asset Management in the Social Rented Sector; Policy and Practice in Europe and Australia. Dordrecht: Kluwer Academic Publishers, 39-59.

Boelhouwer, P., Boumeester, H., and van der Heijden, H. (2006) Stagnation in Dutch Housing Production and Suggestions for a Way Forward. Journal of Housing and the Built Environment, 21 (3), 299-314.

Buitelaar, E., and De Kam, G. (2011) The Emergence of Inclusionary Housing: Continuity and Change in the Provision of Land for Social Housing in the Netherlands. Housing, Theory and Society, 29 (1), 56-74.

Carmona, M., Carmona, S., and Gallent, N. (2003) Delivering New Homes. Processes, Planners and Providers. London: Routledge.

CBS Statistics Netherlands. (July 2012) Over a Quarter of Tenants in Housing Association Stock Earn more than 33 Thousand Euro. www.cbs.nl/en-GB/menu/themas/bouwen-wonen/publicaties/artikelen/ archief/2012/2012-3652-wm.html 
CECODHAS (2012) Impact of the Crisis and Austerity Measures on the Social Housing Sector. Brussels: CECODHAS Housing Europe Observatory Research Briefing, 5 (2).

Czasny, M., and Bständig, T. (2008) Housing Conditions in Vienna-Changes as Mirrored in the Austrian Micro Census, Vienna Housing Research. www.wohnbauforschung.at/en/Projekt_Mikrozensus.html

Doling, J. (1997) Comparative Housing Policy: Government and Housing in Advanced Industrialised Countries. New York: St. Martin's Press, Inc.

Donner, C. (2000) Housing Policies in the European Union: Theory and Practice. Vienna: Donner.

Esping-Andersen, G. (1990) The Three Worlds of Welfare Capitalism. Cambridge: Polity Press.

Förster, W., and Menking, W. (eds). (2019) The Vienna Model 2: Housing for the City of the 21st. Berlin: Jovis.

Gilderbloom, J. G., Hanka, M., and Lasley, C. B. (2009) Amsterdam: The Ideal City, Policy and Planning. Local Environment: The International Journal of Justice and Sustainability, 14 (6), 373-392.

Gruis, V., Elsinga, M., Wolters, A., and Priemus, H. (2005). Tenant Empowerment through Innovative Tenures: An Analysis of Woonbron Maasoevers' Client Choice Programme. Housing Studies, 20 (1), 127-147.

Jensen, L. (2013). Housing Welfare Policies in Scandinavia: A Comparative Perspective on a Transition Era. LHI Journal of Land, Housing, and Urban Affairs, 4 (2), 133-144.

Kemeny, J. (1995) From Public Housing to the Social Market: Rental Policy Strategies in Comparative Perspective. London and New York: Routledge.

Kemeny, J., Kersloot, J., and Thalmann, P. (2005) Non-Profit Housing Influencing, Leading and Dominating the Unitary Rental Market: Three Case Studies. Housing Studies, 20 (6), 855-872.

Kemeny, J., and Lowe, S. (1998) Schools of Comparative Housing Research: From Convergence to Divergence. Housing Studies, 13 (2), 161-176.

Matznetter, W. (2002) Social Housing Policy in a Conservative Welfare State: Austria as an Example. Urban Studies, 39 (2), 265-282.

McCarthy, D., Crandall, D., Whitelaw, G., General, Z., and Tsuji, L. (2011). A Critical Systems Approach to Social Learning: Building Adaptive Capacity in Social, Ecological, Epistemological (SEE) Systems. Ecology and Society, 16 (3), 18.

Ministry of Welfare. (2009). Committee Report on the Financing of Third-Sector Housing. www.vfm. $\mathrm{dk} /$ Publikationer/Sider/VisPublikation.aspx?Publication=356

Mundt, A., and Amann, W. (2019) “Wiener Wohnbauinitiative": A New Financing Vehicle for Affordable Housing in Vienna, Austria. In G. van Bortel, V. Gruis, J. Nieuwenhuijzen, and B. Pluijmers (eds)., Affordable Housing Governance and Finance: Innovations, Partnerships and Comparative Perspectives. Abingdon: Routledge, pp. 187-209.

Nielsen, B. G. (2010). Is Breaking Up Still Hard to Do?-Policy Retrenchment and Housing Policy Change in a Path Dependent Context. Housing, Theory and Society, 27 (3), 241-257.

Oxley, M. (1995) Private and Social Rented Housing in Europe: Distinctions, Comparisons and Resource Allocation. Scandinavian Housing and Planning Research, 12, 59-72.

Poggio, T., and Whitehead, Ch. (2017) Social Housing in Europe: Legacies, New Trends and the Crisis. Critical Housing Analysis, 4 (1), 1-10.

Scanlon, K., Fernández Arrigoitia, M., and Whitehead, C. M. (2015). Social Housing in Europe. European Policy Analysis, 17, 1-12.

Scanlon, K., and Vestegaard, H. (2007). Social Housing in Denmark. In C. M. E. Whitehead \& K. Scanlon (eds)., Social Housing in Europe. London: London School of Economics and Political Sciences, pp. 44-54.

Statistics Austria. (2012). Housing Costs. Vienna: National Statistical Institute. www.statistik.at/web_en/ statistics/dwellings_buildings/housing_costs/index.html

Tsenkova, S. (2009) Housing Reforms in Post-socialist Europe. Lost In Transition. Heidelberg: Springer-Verlag.

Tsenkova, S. (2014) A Tale of Two Cities: Resilience of Social Housing in Vienna and Amsterdam [Krisenfestigkeit der sozialen Wohnungssektoren in Wien und Amsterdam]. In, W. Amann, H. Pernsteiner, and Ch. Struber (eds)., Wohnbau in Osterreich in Europaischer Perspective. Vienna: Manz Verlag and Universitatsbuchhandlung, pp. 95-105. 
Tsenkova, S. (2019) Social Housing on Trial: Institutions + Policy Design. Urban Research and Practice, 12 (1), 1-6.

Tsenkova, S. (2021) Transforming Social Housing: International Perspectives. Abingdon: Routledge.

Tsenkova, S., and Vestegaard, H. (2011) Social Housing Provision in Copenhagen, ENHR Conference, University of Toulouse, July 3-8, Workshop 7, p. 16.

Vale, L., Shamsuddin, S., Gray, A., and Bertumen, K. (2014). What Affordable Housing Should Afford: Housing for Resilient Cities. Cityscape, 16 (2), 21-50.

van der Veer, J., and Schuiling, D. (2005) The Amsterdam Housing Market and the Role of Housing Associations. Journal of Housing and the Built Environment, 20, 167-181.

van Kempen, R., and Priemus, H. (2002) Revolution in Social Housing in the Netherlands: Possible Effects of New Housing Policies. Urban Studies, 39 (2), 237-253.

Walker, B., and Salt, D. (2012) Resilience Practice: Building Capacity to Absorb Disturbance and Maintain Function. Washington, DC: Island Press.

Walker, B., Salt, D., and Reid, W. (2006) Resilience Thinking: Sustaining Ecosystems and People in a Changing World. Washington, DC: Island Press. 